\title{
Penerapan Media Audio Visual untuk Meningkatan Perilaku Cinta Lingkungan pada Golden Age
}

\author{
Lely Suryani ${ }^{1}$, Stefania Baptis Seto ${ }^{\bowtie}$ \\ Pendidikan Matematika Universitas Flores \\ DOI: $10.31004 /$ obsesi.v5i1.601
}

\begin{abstract}
Abstrak
Penelitian ini bertujuan untuk mengetahui adanya peningkatan perilaku cinta lingkungan menggunakan media audiovisual tentang kegiatan membuang sampah pada tempatnya. Penelitian ini menggunakan jenis Penelitian Tindakan Kelas (PTK) dengan metode deskriptif kualitatif melalui observasi langsung, wawancara dan dokumentasi yang melibatkan 18 siswa/i kelas B2 TK Kartika Kodim Ende. Berdasarkan hasil penelitian, dapat disimpulkan bahwa: 1) Perencanaan dan pelaksanaan pembelajaran dengan menggunakan video terkait kegiatan membuang sampah pada tempatnya di TK Kartika Kodim Ende berada pada kategori baik. Dalam hal ini langkah-langkah yang dilakukan guru berdasarkan perencanaan yang telah dibuat meliputi; a) pemberian pemahaman kegiatan memilah dan menempatkan sampah pada tempatnya b) menyedikan bak sampah terpilah jenis organik dan anorganik, serta c) memperaktekkan pemilahan dan penempatan sampah sesuai jenisnya ditempat yang benar, 2) Perilaku cinta lingkungan melalui kegiatan membuang sampah pada tempatnya berkembang sangat baik dan mengalami peningkatan sebesar $45 \%$. Dimana siklus I sebesar $55 \%$ meningkat menjadi $100 \%$ pada siklus ke II.
\end{abstract}

Kata Kunci: perilaku, cinta lingkungan; video; tk kartika kodim ende.

\begin{abstract}
This study aim to determine the behaviour of love the environment using audiovisual media on the activity of disposing of garbage in its place. This study used Classroom Action Research (CAR) with qualitative descriptive method through observation, interviews and documentation that involved 18 students of class B2 TK Kartika Kodim Ende. From the findings, it can be concluded that: 1) Planning and implementation of learning using videos related to waste disposal activities at TK Kartika Kodim Ende on the level of good. In this case, the steps taken by the teachers based on the planning that has been made; a) give the understanding of sorting and placing garbage in its place, $b$ ) provide the organic and inorganic waste bins, and c) practice the sorting and placing garbage according to its type on the right bins, 2) Behaviour of love the environment through the activities of disposing of garbage in its place is very well developed and $45 \%$ increased. Where in the cycle I increased by $55 \%$ to $100 \%$ in cycle II.
\end{abstract}

Keywords: behaviour of love the environment; garbage, video; tk kartika kodim ende.

Copyright (c) 2020 Lely Suryani, Stefania Baptis Seto

$\triangle$ Corresponding author:

Email Address : lelypane@gmail.com ( Sam Ratulangi, Nusa Tenggara Timur, Indonesia )

Received 16 June 2020, Accepted 4 September 2020, Published 11 September 2020 


\section{PENDAHULUAN}

Lingkungan hidup saat ini dalam keadaan yang sangat memprihatinkan. Dapat kita lihat bumi sekarang dijadikan tempat pembuangan sampah dalam skala besar dan mengakibatkan penurunan kualitas lingkungan hidup. Salah satu hubungan antara penurunan kualitas lingkungan hidup dan manusia (sosial) adalah hasil dari tindakan dan perilaku manusia yang dapat mengakibatkan perubahan-perubahan pada lingkungan hidup (Barry.J, 2007), (Susilo, 2012). Dengan demikian, kepribadian manusia itu sendiri dan situasi/keadaan lingkungan sekitar yang akan mempengaruhi perilaku lingkungan seseorang (Laurens, 2012).

Lingkungan dan manusia merupakan dua hal yang tidak dapat dipisahkan dimana lingkungan sangat mempengaruhi kehidupan manusia. Menurut Otto Soemarwoto, (2001) lingkungan hidup adalah semua benda dan daya serta kondisi, termasuk di dalamnya manusia dan tingkah perbuatannya yang terdapat dalam ruang dimana manusia berada dan mempengaruhi kelangsungan hidupnya serta kesejahteraan manusia. Oleh karena itu, sangat penting untuk menanamkan rasa cinta lingkungan pada anak sejak usia dini untuk tetap menjaga kelestarian lingkungan demi kehidupan generasai yang akan datang.

Perilaku cinta lingkungan pada penelitian ini merupakan perwujudan dari rasa peduli anak-anak usia dini terhadap lingkungan sosial budaya. Dengan demikian dalam penelitian ini perilaku cinta lingkungan pada usia dini lebih difokuskan dengan membuat lingkungan sekolah menjadi indah, asri dan nyaman yang digunakan sebagai tempat untuk melaksanakan kegiatan belajar mengajar. Selain itu hal lain juga difokuskan kepada mengajarkan anak mengenal dan memilah sampah serta membuang sampah pada tempatnya. Menurut Beichler dan Snowman (Yulianti Dwi, 2010) anak usia dini adalah anak yang berusia antara 3-6 tahun. Hakikat anak usia dini adalah individu yang unik dimana ia memiliki pola pertumbuhan dan perkembangan dalam aspek fisik, kognitif, sosio emosional, kretivitas, bahasa dan komunikasi yang khusus dan sesuai dengan tahap yang sedang dilalui oleh anak tersebut.

Masa anak usia dini sering disebut masa "Golden Age" atau masa emas (Augusta, 2012). Menurut Siti Aisyah, (2010) karakteristik anak usia dini antara lain : a) memiliki rasa ingin tahu yang besar; b) merupakan pribadi yang unik; c) suka berfantasi dan berimajinanasi; d) masa paling potensial untuk belajar; e) menunjukkan sikap egosentrik ; f) memiliki rentang daya konsentrasi yang pendek; g) sebagai bagian dari makhluk sosial. Dalam Undangundang Nomor 20 tahun 2003 (Permendiknas No 58 tahun, 2009) tentang sistem Pendidikan Nasional pasal 1 angka 14 menyatakan "pendidikan Anak Usia Dini (PAUD) adalah suatu upaya pembinaan yang ditujuan kepada anak sejak lahir sampai dengan usia 6 tahun yang dilakukan melalui pemberian rangsangan pendidikan untuk membantu pertumbuhan dan perkembangan jasmani dan rohani agar anak memiliki kesiapan dalam memasuki pendidikan lanjut". PAUD merupakan salah satu bentuk penyelenggaraan pendidikan yang menitikberatkan pada peletakan dasar kearah beberapa perkembangan dimana pendidikan anak usia dini merupakan tahap awal anak diberi stimulus bagi tumbuh kembang anak.

Menurut Suryani, Tute, \& Aje, (2019), bagi anak lingkungan sekitar merupakan tempat bermain dan bereksperimen serta bereksplorasi sehingga lingkungan sangat memegang peranan penting dalam pertumbuhan mereka. Ini karena di lingkungan terdapat segala sesuatu yang ada disekitar kita, baik berupa makhluk hidup dan juga benda mati serta semua yang bermanfaat bagi kehidupan kita sebagai manusia. Seperti yang dikatakan oleh Jan Lightghart, sumber utama pembelajaran adalah lingkungan di sekitar anak (Sunanik, 2018 : 89). Agar kecerdasan yang dimiliki oleh anak dapat berkembang secara optimal, potensi bawaan perlu ditumbuhkembangkan melalui berbagai stimulasi dan upaya-upaya dari lingkungan (Ekayanti, 2014). Oleh karena itu untuk beberapa tema yang berkaitan dengan lingkungan sekitar, pendidik bisa mengajak anak untuk melakukan kegiatan pembelajaran di luar kelas sehingga anak dapat bereksplorasi secara langsung dengan benda-benda yang dipelajari sesuai dengan materi dan tema yang diajarkan (Utami, 2020). 
Menurut (Ismail, 2018:17) anak yang menunjukkan minat besar terhadap alam, hewan, dan tumbuhan, meskipun itu terkesan kotor dan berbahaya, harus ditempatkan sebagai belajar. Rangsangan yang tepat akan membuat mereka memiliki karier yang luar biasa dalam berbagai bidang di kemudian hari. Oleh karena itu, jika lingkungan yang ditempatinya bersih dan juga berkualitas maka manusia dalam hal ini lebih ditekankan pada anak-anak akan bertumbuh dan berkembang dengan baik serta berkualitas pula.

Proses pembelajaran yang mengajarkan anak didik untuk mencintai lingkungan hidup seharuskan ditanamkan sejak usia dini sebagai fondasi atau dasar dalam proses pembelajaran. Hal ini agar para peserta didik memiliki pemahaman tentang lingkungan dengan lebih baik lagi sejak awal belajar dilingkungan sekolah. Selanjutnya, masih rendahnya minat belajar anak karena guru hanya terpaku pada buku teks sebagai satu-satunya sumber belajar. Hal ini sesuai dengan penelitian dilakukan oleh Handayani Hilda, Yetri, \& Ganda Putra ferdi, (2018) yang menyatakan bahwa media pembelajaran yang masih terbatas pada buku yang penyajian materinya padat dan tampilannya tidak menarik serta banyaknya soal-soal dan tugas-tugas yang diberikan pendidik sehingga membuat peserta didik bosan untuk belajar.

Salah satu media belajar yang dapat digunakan lebih menarik adalah media audio visual (Video). Pelajaran yang divisualisasikan dalam bentuk gambar animasi lebih bermakna dan menarik, serta lebih mudah diterima, dan dipahami, bahkan lebih dapat memotivasi (Sukiyasa \& Sukoco, 2013). Video adalah teknologi penangkapan, perekaman, pengolahan, penyimpanan, pemindahan dan perekonstruksian urutan gambar diam dengan menyajikan adegan-adegan dalam gerak secara elektronik (Munir, 2012). Video pembelajaran adalah media audio visual yang dapat digunakan untuk menyalurkan pesan serta dapat merangsang pikiran, perasaan, perhatian dan kemauan si pelajar sehingga dapat mendorong terjadinya proses belajar yang disengaja, bertujuan dan terkendali. Kehadiran media audio visual dapat digunakan untuk mencapai pembelajaran, yang merupakan bagian dari sistem pembelajaran (Kristanto, 2011).

Permasalahan lingkungan saat ini hanya bisa diatasi dengan melakukan perubahan cara pandang dan perilaku manusia terhadap alam (Sudjoko et al., 2014). Menurut Irwin \& Bushenell (Sue C. Wortham \& Belinda J. Hardin, 2005) bahwa anak-anak lebih banyak melakukan kegiatan tindakan dari pada berbicara. Oleh Karena itu mengenalkan anak-anak pada lingkungan secara langsung dan menanamkan rasa cinta lingkungan pada anak dengan cara tetap memelihara kebersihan lingkungan dan keasrian lingkungan melalui audio visual sangat dibutuhkan pada anak-anak usia dini saat ini.

Sejalan dengan penelitian (Annisa et al., 2020) dengan judul Peningkatan Pemahaman Berhitung dan Kardinalitas Melalui Penggunaan Media Rankasbitung dapat meningktakan kemampuan berhitung anak usia dini. Hasil penelitian Rupawati, Noviani, \& Ariyanto, (2017) dengan judul penelitian Penerapan Media Pembelajaran Audio Visual untuk meningkatkan hasil belajar ekonomi mendapati bahwa Penerapan Media Pembelajaran Audio Visual dapat meningkatkan hasil belajar ekonomi siswa kelas XI IPS 12 SMAN 5 Surakarta Tahun ajaran 2016/2017. Hal ini juga sejalan dengan penelitian yang dilakukan oleh Sulfemi \& Mayasari, (2019) dengan judul Penerapan Model Pembelajaran Value Clarification Thenique Berbantuan Audio Visual menyimpulkan bahwa Penerapan Model Pembelajaran Value Clarification Thenique Berbantuan Audio Visual dapat meningkatkan motivasi peserta didik dalam proses belajar dan hasil belajar.

Selanjutnya, hasil belajar siswa menggunakan pembelajaran kooperatif yang diintegrasikan dengan media animasi komputer lebih baik secara signifikan (Irham \& Mahmud, 2019). Media pembelajaran Digital Storytelling juga dapat meningkatkan hasil belajar siswa dan terbukti efektif menunjang proses pembelajaran siswa (Prananta, Yunina Resmi; Setyosari, Punandji; Santoso, 2017). Selain itu anak anak juga memiliki kecerdasan Naturalisasi. Kecerdasan naturalis anak dapat dioptimalkan dengan berbagi metode pembelajaran. Hal ini sejalan dengan pendapat (Herwati, 2020: 429) yang menyatakan bahwa anak yang memiliki kecerdasan naturalis lebih senang bermain di luar ruangan. Kecerdasan 
naturalis perlu ditingkatkan untuk memupuk kepedulian anak dengan alam, sehingga anak akan menyayangi dan menjaga alam agar tetap lestari sehingga dapat dimanfaatkan oleh manusia (Maryanti et al., 2019).

Oleh sebab itu peneliti memilih Taman Kanak kanak (TK) Kartika Kodim Ende, karena merupakan TK favorit di kota Ende. Peneliti mencoba mengangkat permasalahan yang perlu diperhatikan untuk lebih lanjut berkaitan dengan permasalahan lingkungan belajar bagi anak didik pada usia dini, sehingga peneliti merasa tertarik mengambil judul untuk penelitian yaitu “Penerapan Media Audio Visual untuk Meningkatan Perilaku Cinta Lingkungan pada Golden Age di Taman Kanak Kanak Kartika Kodim Ende NTT".

Berdasarkan permasalahan umum yang dikemukakan dalam latar belakang maka tujuan umum penelitian ini adalah untuk mendeskripsikan kegiatan, perencanaan pembelajaran, dan tindakan membuang sampah pada tempatnya di sekolah dalam kegiatan meningkatkan perilaku cinta lingkungan pada anak Golden Age di TK Kartika Kodim Ende. Hasil penelitian diharapkan dapat menjadi solusi pemecahan masalah dalam dunia pendidikan dalam segala aspek kecerdasan anak Golden Age khususnya menumbuhkan perilaku cinta lingkungan.

\section{METODOLOGI}

Pendekatan penelitian yang digunakan dalam penelitian ini adalah penelitian Tindakan Kelas (PTK). Penelitian Tindakan Kelas adalah penelitian yang memaparkan terjadinya sebab-akibat dari perlakuan, sekaligus memaparkan apa saja yang terjadi ketika perlakuan diberikan, dan memaparkan seluruh proses sejak awal pemberian perlakuan sampai dengan dampak dari perlakuan tersebut (Arikunto, 2015). Subjek yang terlibat dalam penelitian adalah guru dan anak-anak Taman Kanak-kanak Kartika Kodim Ende. Penelitian akan dilaksanakan di TK Kartika Kodim Ende yang beralamat di jalan Kartini no 02, kelurahan Kota Raja, Kecamatan Ende Utara, Kabupaten Ende Propinsi Nusa Tenggara Timur. Alasan Peneliti memilih Tk Kartika Kodim Ende adalah karena TK ini merupakan salah satu TK favorit di kota Ende dengan waktu penelitian akan disesuaikan dengan jam aktif proses kegiatan belajar mengajar di TK tersebut.

Untuk keperluan pengumpulan data tentang proses dan hasil yang dicapai, teknik yang digunakan yakni teknik pengamatan (observasi), teknik wawancara, dan teknik dokumentasi. Kemmis,S \& Mc. Taggart, (1988) menyatakan bahwa;" Model penelitian tindakan kelas adalah berbentuk spiral. Prosedur penelitian mencakup hal-hal seperti berikut: Perencanaan (planning); Penerapan Tindakan (action); Mengobservasi dan mengevaluasi proses (observation and evaluation) dan melakukan refleksi (reflecting) dan seterusnya sampai perbaikan atau peningktana yang diharapkan tercapai (kriteria keberhasilan).

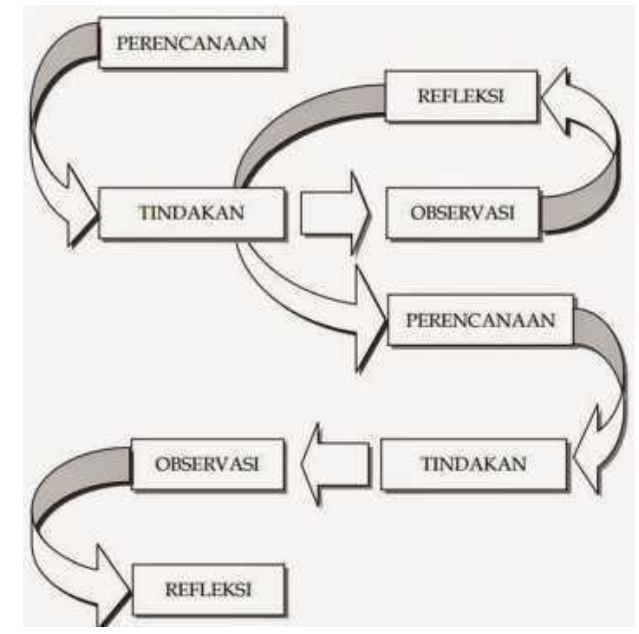

Gambar 1 Siklus PenelitianTindakan Model Kemmis \& Mc Taggart 


\section{HASIL DAN PEMBAHASAN}

Masalah dalam penelitian ini adalah kurangnya kesadaran manusia akan kebersihan lingkungan dan membuang sampah sembarangan. Oleh karena itu penelitian ini secara umum bertujuan untuk merubah cara pandang dan perilaku manusia terhadap alam sejak dini. Secara khusus pula tujuan penelitian ini adalah untuk mengetahui adanya peningkatan perilaku cinta lingkungan dengan menggunakan media audiovisual tentang kegiatan membuang sampah pada tempatnya di Taman Kanak-kanak Kartika Kodim Ende. Perilaku cinta lingkungan melalui proses pembelajaran dengan menggunakan audiovisual pada siklus I dan siklus II mengalami peningkatan. Sebelum Kegiatan di mulai, peneliti meminta anakanak TK KArtika Kodim Kelas B untuk meperkenalkan diri masing -masing dan mereka sangat antusias, seperti yang terlihat pada gambar 2 .

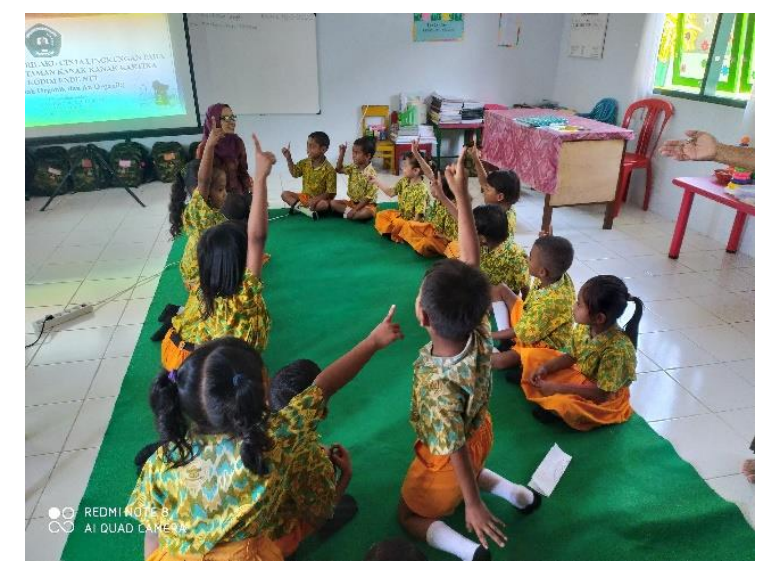

\section{Gambar 2. Foto Anak-anak TK Kartika Kodim kelas B}

Penelitian ini dilaksanakan dalam dua siklus. Penggunaan media audio visual untuk meningkatkan perilaku cinta lingkungan pada golden age. Dalam proses perencanaan pembelajaran yang dilaksanakan oleh peneliti pada langkah awal adalah menyiapkan dan menyusun Rencana Pelaksanaan Pembelajaran Harian (RPPH) dengan menggunakan media audiovisual dalam hal ini menggunakan video berdasarkan pedoman yang diberikan oleh guru kelas yang menjadi tempat penelitian yaitu kelas B pada TK Kartika VII-8 Ende. RPPH yang telah disusun merupakan pedoman pelaksanaan pembelajaran yang akan dilaksanakan dalam waktu 1 minggu yaitu untuk 2 siklus penelitian. Hasil perencanaan pada siklus I dan siklus II dapat dilihat pada tabel Berikut:

Tabel I Rekapan Hasil Perencanaan dan Pelaksanaan Pembelajaran

\begin{tabular}{clcc}
\hline No. & Aspek Pengamatan & Siklus I & Siklus II \\
\hline 1. & $\begin{array}{l}\text { Pemberian Pemahaman Kegiatan Memilah Dan } \\
\text { Menempatkan Sampah Pada Tempatnya melalu }\end{array}$ & $50 \%$ & $97 \%$ \\
& $\begin{array}{l}\text { video } \\
\text { 2. }\end{array}$ & $54 \%$ & $100 \%$ \\
$\begin{array}{l}\text { Menyedikan Bak Sampah Terpilah Jenis Organik } \\
\text { Dan Anorganik }\end{array}$ & $\begin{array}{l}\text { Mempraktekkan Pemilahan Dan Penempatan } \\
\text { Sampah Sesuai Jenisnya Ditempat Yang Benar }\end{array}$ & \multicolumn{1}{c}{ Rata-Rata } & $100 \%$ \\
\hline
\end{tabular}

Pada siklus I tahap pelaksanaan disesuaikan dengan langkah-langkah yang disusun pada RPPH. Ada 4 langkah utama yang terdapat dalam RPPH yaitu langkah awal, kegiatan Inti, kegiatan istirahat, dan kegiatan akhir. Dimana pada tiap langkah ada poin-poin yang 
menunjukkan atau mengajarkan siswa sesuai tema yang dipelajari berkaitan dengan lingkungan hidup dan sub tema tentang sampah.

Dari keempat langkah yang ada dalam RPPH kemudian dirangkumkan ke dalam 3 aspek pengamatan yaitu (a) pemberian pemahaman kegiatan memilah dan menempatkan sampah pada tempatnya melalui pemberian video, b) menyediakan bak sampah terpilah jenis organik dan anorganik, serta c) memperaktekkan pemilahan dan penempatan sampah sesuai jenisnya ditempat yang benar. Pelaksanaan tindakan pada siklus II merupakan penyempurnaan semua tindakan pada siklus I yang masih dirasa kurang dari hasil refleksi yang dilakukan oleh guru bersama peneliti.
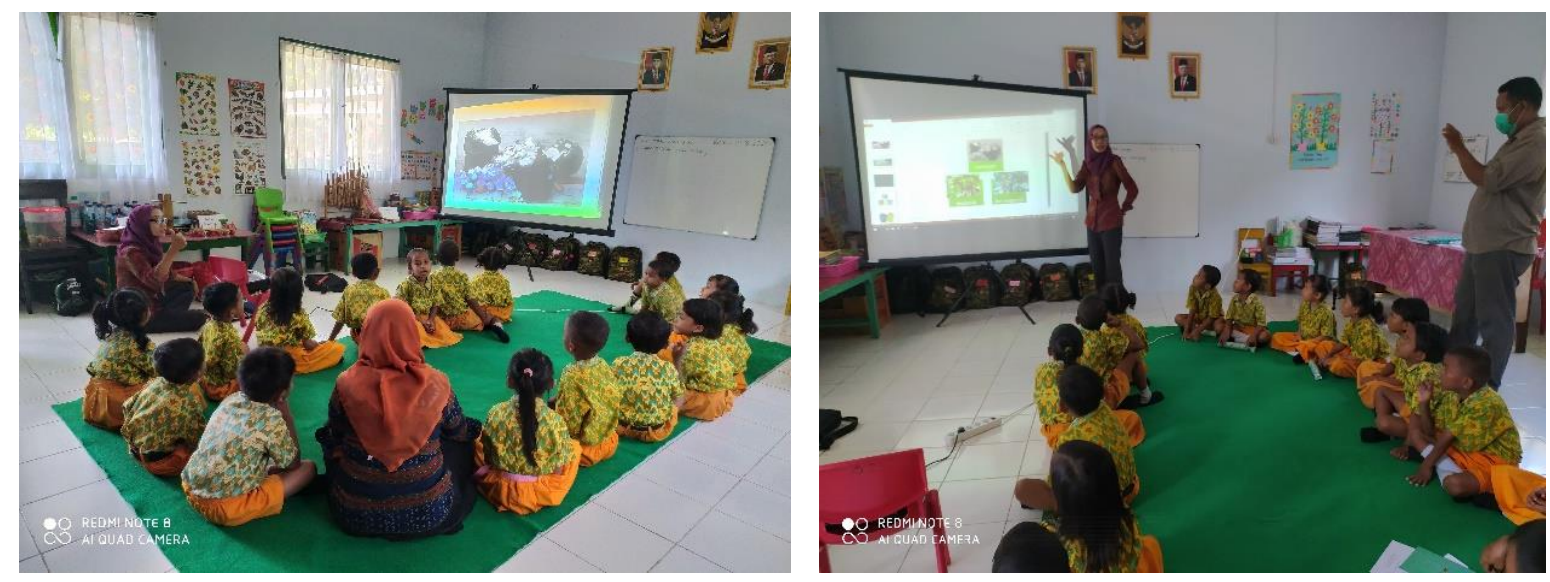

Gambar 3. Aktivitas Pemberian pemahaman kegiatan memilah dan menempatkan sampah pada tempatnya.

Perencanaan dan pelaksaaan pada siklus I dan Siklus II mengalami perubahan seperti data yang tampak pada tabel 1. Untuk aspek pengamatan untuk poin (a) pemberian pemahaman kegiatan memilah dan menempatkan sampah pada tempatnya melalui pemberian video, mengalami peningkatan $47 \%$ dari siklus I dengan presentase $50 \%$ ke siklus II dengan presentase $97 \%$. Untuk poin b) menyediakan bak sampah terpilah jenis organik dan anorganik mengalami peningkatan sebesar 46\% dari siklus I dengan Presentase 54\% ke siklus II mencapai $100 \%$ serta untuk poin c) memperaktekkan pemilahan dan penempatan sampah sesuai jenisnya ditempat yang benar mengalami peningkatan sebesar $40 \%$ dari siklus I dengan Presentase $60 \%$ ke siklus II dengan Presentase 100\%. Dengan melihat adanya peningkatan presentase dari siklus I ke siklus II maka dapat disimpulkan bahwa Perencanaan dan pelaksanaan pembelajaran kegiatan membuang sampah pada tempatnya di TK Kartika Kodim Ende dengan kategori baik.

Data aktivitas siswa pada siklus I dan Siklus II dianalisis dari lembar observasi yang dicentang oleh guru kelas yaitu Ibu Nurhayati S.Pd AUD dimana peneliti menggantikan peran guru sebagai pengajar dimana peneliti menggunakan video sebagai media untuk menjelaskan tentang pengertian sampah, manfaat/kegunaan sampah, memilah sampah sesuai jenisnya yaitu sampah organik dan sampah anorganik, serta mengarahkan siswa untuk membuang sampah pada tempatnya sesuai dengan jenisnya.

Tabel 2. Data Aktivitas Belajar Siswa

\begin{tabular}{cccc}
\hline No. & Aspek yang diamati & Siklus 1 & Siklus 2 \\
\hline 1. & Berada dalam Tugas & $55 \%$ & $100 \%$ \\
2. & Mengetahui Apa Itu Sampah & $60 \%$ & $100 \%$ \\
3. & Sikap Peduli Terhadap Sampah & $65 \%$ & $100 \%$ \\
4. & Penutup & $57 \%$ & $100 \%$ \\
\hline & Skor rata-rata & $60 \%$ & $100 \%$ \\
\hline
\end{tabular}


Dari hasil analisis pada tabel 2, dapat dilihat peningkatan untuk tiap aspek pengamatan dari siklus I ke siklus II untuk 4 aspek pengamatan yaitu untuk aspek (1) Berada dalam tugas, setiap siswa melakukan kegiatan pembelajaran dengan baik dan mengamati dengan seksama isi dari video serta mengikuti semua arahan dari guru, hal ini dapat dilihat dari presentasi pada siklus I sebesar 55\% ke siklus II 100\% yang mengalami peningkatan sebesar $45 \%$, (2) Mengetahui apa itu sampah, pada poin ini siswa diarahkan untuk mampu memberikan contoh sampah, memilah sampah dan menempatkan sampah pada tempat sampah dengan baik dan benar, dapat dilihat pada 4 dibawah ini
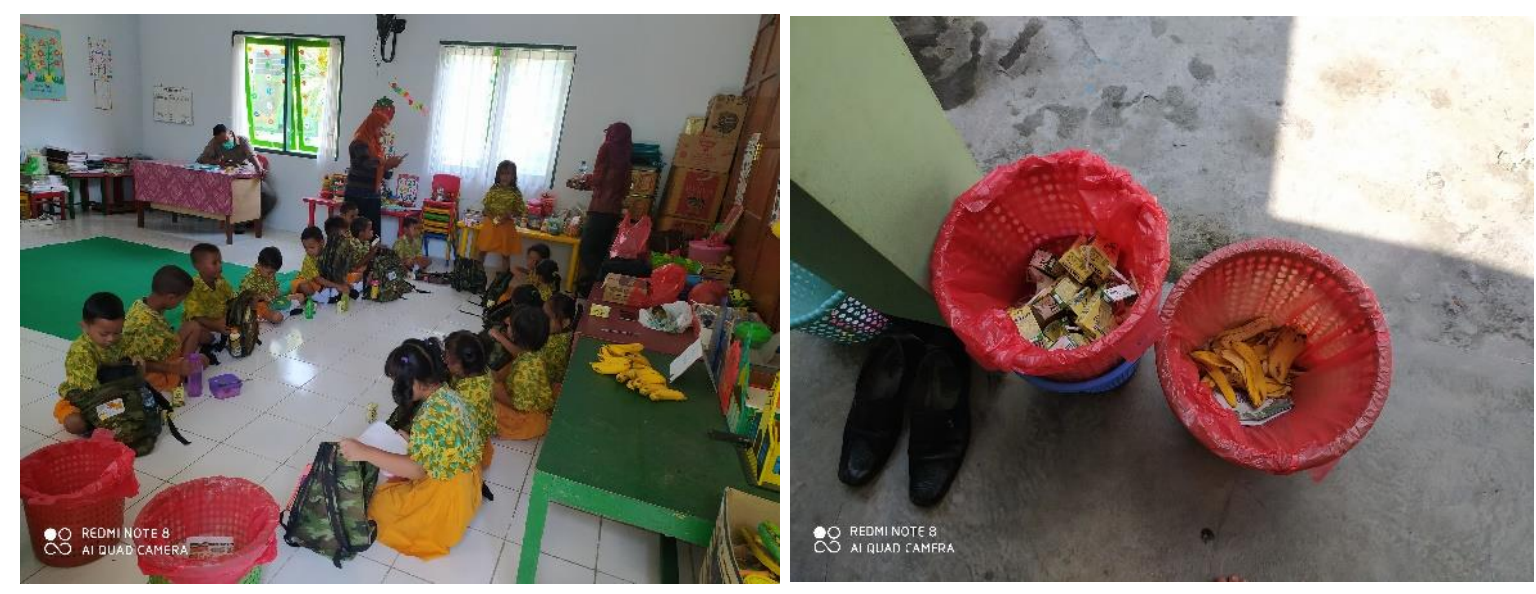

\section{Gambar 4 : Prilaku membuang sampah pada tempatnya}

Pada poin 2 ini hasil peningkatannya dapat dilihat dari presentase pada siklus I ke siklus II dengan peningkatan sebesar 40 \%, (3) Sikap Peduli terhadap Sampah pada poin ini siswa diarahkan agar mampu menumbuhkan sikap memungut sampah yang berserakan tanpa disuruh, siswa mampu mengajak teman untuk ikut memungut sampah. Pada poin ini presentasinya mengalami peningkatan sebesar $35 \%$, dan pada poin (4) penutup, pada poin ini siswa diarahkan agar mampu memberikan respon balik dari keseluruhan rangkaian kegiatan berkaitan dengan sampah. Pada poin ini juga mengalami peningkatan dari siklus I ke siklus II dengan peningkatan sebesar $43 \%$. Secara keseluruhan hasil observasi partisipasi siswa presentasinya mengalami peningkatan sebesar $39 \%$.

Untuk data aktivitas guru yang dilaksanakan oleh peneliti, dapat dilihat pada table 3 dibawah ini:

Tabel 3. Data Aktivitas Guru

\begin{tabular}{llccc}
\hline No & \multicolumn{1}{c}{ Uraian } & Siklus I & Siklus II & Peningkatan Tiap Siklus \\
\hline 1 & Total Skor & 32 & 47 & 15 \\
2 & Ketercapaian & $78 \%$ & $91,15 \%$ & $13,15 \%$ \\
\hline
\end{tabular}

Aktivitas peneliti dalam pembelajaran menggunakan media audio visual pada siklus I sebesar $78 \%$ dan siklus II sebesar $91,15 \%$. Ini menunjukkan adanya peningkatan aktivitas yang dilakukan oleh peneliti yaitu dari siklus I ke siklus II meningkat sebesar 13,15\%. Berdasarkan hasil ini dapat disimpulkan bahwa adanya peningkatan aktivitas peneliti dalam pembelajaran menggunakan media audio visual.

\section{SIMPULAN}

Mencintai dan peduli pada lingkungan sekitar, adalah karakter yang patut kita ajarkan kepada Golden Age. Dengan ditanamkan rasa mencintai dan peduli lingkungan sejak dini, akan membentuk anak menjadi generasi penerus bangsa yang nantinya lebih peduli dan menghargai kekayaan alam dan akan menjaganya tetap lestari. Dengan menggunakan media 
DOI: 10.31004/obsesi.v5i1.601

audiovisual dalam hal ini penggunaan video sangat berperan dan mempengaruhi daya ingat anak menerapkan pola hidup sehat tentang bagaimana cara anak untuk peduli dengan lingkungannya. Hal ini sejalan dengan Sukiyasa \& Sukoco,(2013) bahwa pelajaran yang dibuat ke visualisasi dalam bentuk gambar animasi lebih bermakna dan menarik, lebih mudah diterima, dipahami, lebih dapat memotivasi.

\section{DAFTAR PUSTAKA}

Annisa, E. N., Supriyati, Y., \& Nurani, Y. (2020). Peningkatan Pemahaman Berhitung dan Kardinalitas melalui Penggunaan Media Rangkasbitung. Jurnal Obsesi: Jurnal Pendidikan Anak Usia Dini, 4(2), 665. https://doi.org/10.31004/obsesi.v4i2.441

Arikunto. (2015). Prosedur Penelitian Suatu Pendekatan Praktik. Rineka Cipta.

Augusta. (2012). Pengertian Anak Usia Dini.

Barry.J. (2007). Enviroment and Social Theory. London.

Ekayanti, Y. (2014). Mengembangkan Kecerdasan Naturalis Tentang Lingkungan Prasekolahanak Usia 5-6 Tahun Tk Lkia Iii Pontianak. Artikel Ilmiah, 13.

Handayani Hilda, Yetri, \& Ganda Putra ferdi. (2018). Pengembangan Media Pembelajaran Berbasis Macromedia Flash. Al-Khwarizmi: Jurnal Pendidikan Matematika Dan Ilmu Pengetahuan Alam, 1(2), 87-100. https:// doi.org/10.24256/jpmipa.v1i2.95

Irham, W. H., \& Mahmud, M. (2019). Peningkatan Hasil Belajar Siswa dengan Pembelajaran Kooperatif dan Penggunaan Media Animasi Komputer. Talenta Conference Series: Science and Technology (ST), 2(1), 241-245. https://doi.org/10.32734/st.v2i1.350

Ismail, A. (2018). Pengembangan Instrumen Kecerdasan Naturalis Anak Usia Dini Di Kabupaten Luwu Timur Provinsi Sulawesi Selatan. Jurnal Evaluasi Pendidikan, 9(1), 16-29.

Kemmis,S \& Mc. Taggart, R. (1988). The Action Research Planner. Victoria: Deakin. University Press.

Kristanto. (2011). Pengembangan Model Media Video Pembelajaran Mata Kuliah Pengembangan Media Video/TV Prodi Teknologi Pendidikan Fakultas Ilmu Pendidikan Universitas Negeri Surabaya. Universitas Negri Surabaya, Jurnal Teknologi Pendidikan, Vil11, N0. 1 April 2012.

Laurens, J. . (2012). Changing Behavior and Environment in a Community-Based Program of the Riverside Community.

Maryanti, S., Kurniah, N., \& Yulidesni, Y. (2019). Meningkatkan Kecerdasan Naturalis Anak Melalui Metode Pembelajaran Outing Class Pada Kelompok B Tk Asyiyah X Kota Bengkulu. Jurnal Ilmiah POTENSIA, 4(1), 22-31. https:/ / doi.org/10.33369/jip.4.1.22-31

Munir. (2012). Multimedia: Konsep dan Aolikasi dalam Pendidikan. Alpfabeta.

Otto Soemarwoto. (2001). No TitleEkologi Lingkungan Hidup. Djembatan.

Prananta, Yunina Resmi; Setyosari, Punandji; Santoso, A. (2017). Pengembangan Media Boneka Tangan Berbasis Digital Storytelling. Jurnal Pendidikan: Teori, Penelitian, Dan Pengembangan, 2(5), 627-636. https:// doi.org/10.17977/jptpp.v2i5.10332

Rupawati, D., Noviani, L., \& Ariyanto, J. (2017). Penerapan Media Pembelajaran Audio Visual. Jurnal Pendidikan Ekonomi Manajemen Dan Keuangan, 1(1), 21-30.

Siti Aisyah. (2010). Perkembangan dan Konsep Dasar Pengembangan Anak Usia Dini. Universitas Terbuka. 
Sudjoko, Maryam, Siti, S.Agung Wijaya, Setianingsih, Wita, Hidayanti, \& Sukarni. (2014). Pendidikan Lingkungan Hidup. In: Perkembangan dan Konsep Dasar Pendidikan Lingkungan Hidup. Universitas Terbuka.

Sue C. Wortham, \& Belinda J. Hardin. (2005). Assessment in Early Childhood Education. Pea.

Sukiyasa, K., \& Sukoco, S. (2013). Pengaruh media animasi terhadap hasil belajar dan motivasi belajar siswa materi sistem kelistrikan otomotif. Jurnal Pendidikan $\quad$ Vokasi, 126-137. https:/ / doi.org/10.21831/jpv.v3i1.1588

Sulfemi, W. B., \& Mayasari, N. (2019). Peranan Model Pembelajaran Value Clarification Technique Berbantuan Media Audio Visual Untuk Meningkatkan Hasil Belajar Ips. Jurnal Pendidikan, 20(1), 53. https:/ / doi.org/10.33830/jp.v20i1.772.2019

Sunanik, S. (2018). Pembelajaran Berbasis Alam Untuk Anak Usia Dini Di Tk Alam Alazhar Kutai Kartanegara. Al-Madrasah: Jurnal Pendidikan Madrasah Ibtidaiyah, 3(1), 81-110. https://doi.org/10.35931/am.v0i0.71

Suryani, L., Tute, K. J., \& Aje, A. U. (2019). Penumbuhan Karakter CInta Lingkungan Hidup Melalui Kegiatan-Kegiatan Di Organisasi Anak Cinta Lingkungan Kabupaten Ende NTT. 4(2), 23-34. https://doi.org/http:/ /dx.doi.org/10.24127/jlpp.v4i2.1082

Susilo, R. K. . (2012). Sosiologi Lingkungan. PT. Rajagrafindo Persada.

Utami, F. (2020). Pengaruh Metode Pembelajaran Outing Class Terhadap Kecerdasan Naturalis Anak Usia 5-6 Tahun. Jurnal Obsesi: Jurnal $\begin{array}{llll}\text { Pendidikan Anak Usia } & \text { 428-437. }\end{array}$ https:/ / doi.org/10.31004/obsesi.v4i1.358

Yulianti Dwi. (2010). Bermain Sambil Belajar Sains Di Taman Kanak-Kanak. PT INdeks. 